$$
\begin{array}{ll}
\text { УДК } \quad 355.58 \\
\\
504.1 \\
\text { 627.14(497.11)"2014" } \\
\text { COBISS.SR-ID 513528501 }
\end{array}
$$

https://doi.org/10.18485/fb_godisnjak.2019.5

\title{
СИСТЕМ ОБНОВЕ И ПОМОЋИ - ТЕОРИЈСКЕ ОСНОВЕ И ФУНКЦИОНИСАҢЕ У РЕПУБЛИЦИ СРБИЈИ
}

\author{
Проф. др Ивица Ђорђевић* \\ Универзитет у Београду, Факултет безбедности
}

Сандра Недељковић ${ }^{* *}$, мастер политикологије Канцеларија за управљање јавним улагањима

* djivica@gmail.com

** sandra.nedeljkovic@obnova.gov.rs 



\section{СИСТЕМ ОБНОВЕ И ПОМОЋИ - ТЕОРИЈСКЕ ОСНОВЕ И ФУНКЦИОНИСАЊЕ У РЕПУБЛИЦИ СРБИЈИ}

Сажетак: Систием обнове и йомоћи је синйаімма која најбоље ойисује иелину йроцеса суочавана са йослеgицама елеменитарних и gруіих нейоїgа. Ефикасна обнова йодразумева бројне елемение и оgїоварајућу

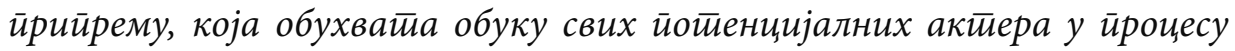

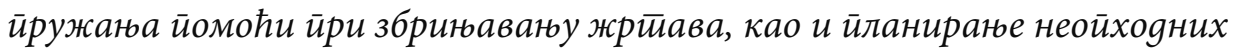

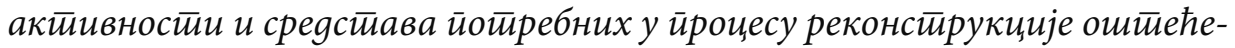
них и изіраяюе нових објекатиа. Учестилости и размере елементиарних и gруіих нейоїоgа са кайастирофалним йослеgицама, ${ }^{1}$ које йревазилазе кайацииетеие националних яржава, условили су изіраgюу међународноі си-



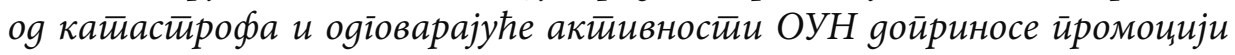
метиодолоіије настиале на ранијим искустивима. Усйосйављағе међународноі механизма за йружане йомоћи йакође дойриноси ефикасностии

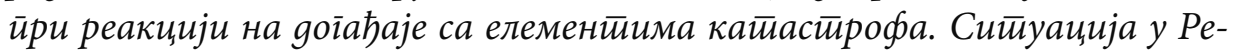
йублици Србије након мајских ӣойлава 2014. іолине йойврђује значај йостиојаюа инстиитуционалних механизама за ефикасно суочаване са елементиарним и gруіим нейоїодама. С обзиром gа национални систем

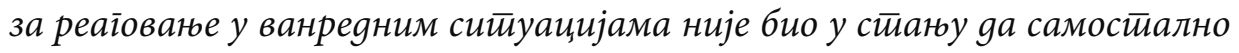
реши ирроблем, захвальујуи йомоћи међународних оріанизација и држава које су йослале своје сиечијализоване снайе Рейублика Србија је усиеела gа се избори са йослеgицама йойлава. Уйраво збоі йоїа овај иекссй указује на значај конииинуираної раgа и иррииррема, како би зајеgница била у сйаюу не само gа се суочи са йослеgицама, већ и gа йреgуйреgи настиајате gоіађаја који моїу gа изазову кайасйрофалне йослеgице.

Кључне речи: сисиемм, обнова, йомоћ, нейоїоgе, мајске йойлаве

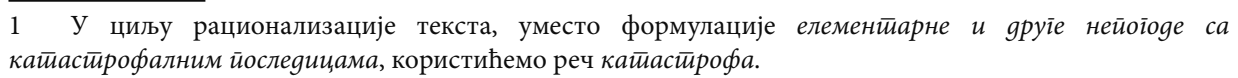




\section{Увод}

Опште обележје елементарних и других непогода је да поред људског страдања изазивају и велика материјална разарања (Clement, 1989). Овакви догађаји уносе изразит стрес у људске системе и структуре, јер су у њихово одвијање укључене снаге веће од оних са којима се систем и структуре обично носе. Обим штете је, по правилу, у корелацији са развијеношћу простора и улагањима у систем заштите од догађаја који су изазвали разарања. Сиромашнији региони мање улажу у превенцију, те су самим тим и рањивији у односу на потенцијалне ризике. Фондови за реаговање у условима ванредних ситуација су ограничени и захтевају рационалан однос према исказаним потребама. Треба ускладити краткорочне активности усмерене ка решавању тренутних проблема на погођеном подручју са дугорочним циљевима подизања отпорности у односу на потенцијалне ризике. Усклађивање наведеног циља захтева свеобухватан приступ, који подразумева одређене активности пре догађаја, тренутно реаговање у току и/или непосредно након догађаја, као и дугорочну обнову погођеног подручја.

\section{Теоријске основе}

Кроз своју историју човечанство је често било суочено са природним и техничким непогодама (катастрофама) које су за последицу имале велики број жртава и значајна разарања материјалних добара. Катастрофе, које обично доводе до ванредних ситуација, дешавају се у свим деловима света, како у слабо насељеним руралним тако и густо насељеним урбаним регионима, као и у околностима које укључују природне, али и људским деловањем условљене опасности. Релативна учесталост и размере катастрофа наметнули су потребу за систематичним приступом како би се последице непогода свеле на минимум.

Логично је да су најдаље у суочавању са елементарним и другим непогодама отишла најразвијенија друштва. Финансијски потенцијал и материјално-техничка база омогућили су развијеним земљама да изграде најбоље системе за реаговање у ванредним ситуацијама. Сложеност процеса условљава потребу за изградњом модела поступања, односно изучавања процеса у циљу извлачења општих законитости како би се што боље припремили за могуће догађаје са катастрофалним последицама. Припрема подразумева одређену инфраструктуру и оспособљавање кадрова који су ангажовани у процесу суочавања са последицама елементарних и других непогода. 


\section{Системе обнове и йомоћи}

Систем обнове и помоћи (ОиП) је синтагма која је искоришћена у процесу креирања мастер курса на Факултету безбедности (ФБ, 2017), са идејом да се укаже на сложеност процеса обнове и чињеницу да је она тешко одвојива од осталих фаза у процесу суочавања са последицама елементарних и других непогода. У доступној литератури на енглеском језику користе се појмови попут: Disaster Recovery, Reconstruction, Restoration, Rebuilding, Sustainable Disaster Recovery, Disaster resistance, Hazard mitigation (UNISDR, 2009; ОЕБС, 2004), који у зависности од контекста објашњавају неки од аспеката процеса ОиП.

Суштина је да се у односу на исту појаву некада користе другачији појмови као синоними, како би се објаснило одвијање процеса након догађаја који је изазвао ванредну ситуацију. ${ }^{2}$ Сматрамо да је синтагма ОиП прихватљива, јер одражава праву природу активности предузетих у процесу суочавања са последицама елементарних и других непогода. Елементи система ОиП инволвирани су у све фазе управљања ванредним ситуацијама. За нас је битно да укажемо на повезаност фаза и преклапања која постоје у току суочавања са последицама елементарних и других непогода. Наиме, ефикасна и одржива обнова зависи, између осталог, и од квалитета планова, односно процене потенцијалних ризика и претњи. Након што је дошло до елементарне или друге непогоде неопходно је хитно збрињавање жртава и предузимање поступака којима ће се последице катастрофе свести на што мању меру, при томе имајући у виду касније активности. У последњој фази долази до нормализације живота на погођеном простору, уз поштовање принципа да се обнова предузима под императивом - изградити боље, односно сигурније.

На различит приступ процесу обнове након елементарних и других непогода са катастрофалним последицама, указује и чињеница да поједини аутори ограничавају период обнове само на фазу након стабилизације ситуације, односно након ургентног збрињавања угрожених и стављања под контролу процеса који су изазвали догађај (Lindell, 2013: 812). Међутим, Kates и Pijawka (1977) предлажу четворофазни модел процеса обнове који чине: период хитних интервенција; период поправки, период замене уништених објеката и период реконструкције. Фаза реконструкције по овим ауторима подразумева и развојну компоненту, која представља прилику за побољшање услова у односу на стање пре догађаја (Alexander, 1999: 445).

2 Разлике у приступу истом проблему могу да се објасне, између осталог, и друштвеним контекстом из кога потичу аутори. За ширу расправу на ову тему препоручујемо читање књиге под насловом: What is a Disaster? Perspectives on the Question (Quarantelli, 1998). 
Међународна стратегија за смањење ризика од катастрофа (International Strategy for Disaster Reduction - ISDR) одређује обнову након катастрофе као процес који обухвата: „одлуке и радње предузете након катастрофе с циљем враћања услова живота погођене заједнице на ниво пре катастрофе или њиховог побољшања, истовремено охрабрујући и олакшавајући неопходне активности ради смањења ризика од катастрофа“. На приступ изложен у ISDR надовезује се Биро за иревенцију и ойоравак криза (Bureau for Crisis Prevention and Recovery - BCPR) развојног програма ОУН (United Nations Development Programme - UNDP), који каже да успешна обнова подразумева изградњу националних капацитета и постојање одговарајућих механизама у функцији процеса обнове који треба да допринесу јачању заједнице и утврђивању узрока рањивости због којих су друштва подложна катастрофама (UNDP \& EC, 2011: 11).

За свеобухватан приступ процесу обнове након елементарних и других непогода треба имати у виду да је реч о ширем процесу од самог враћања у стање пре догађаја. Не ради се само о поновној изградњи објеката, већ преобликовању физичког, социјалног, економског и природног окружења. Наиме, свеобухватно објашњење процеса обнове након елементарних и других непогода треба да укључи бројне изазове с којима се људи суочавају и катастрофалне последице догађаја по људе као индивидуе и чланове заједнице (породице, неформалне групе, привредне организације, локалне заједнице, државе), као и на природни амбијент. При анализи процеса обнове треба имати у виду да појединци, групе и институције могу бити погођени различитим интензитетом ефеката изазваних елементарним и другим непогодама, те зато процес обнове није нужно линеаран и није само технички изазов већ има и значајну социјалну димензију. Зато можемо рећи да је обнова процес у коме се спроводе друштвене и економске активности које се не ограничавају само на поправке или замену физичких објеката оштећених током катастрофа, већ подразумевају, поред обнове привредних активности, и успостављање (одржање) социјалне стабилности заједнице путем циљаних програма (Nakagawa \& Shaw, 2004). Ови програми подразумевају дугорочне развојне активности, чија је сврха да ојачају укупне капацитете и способности државе да ефикасно управља свим врстама ванредних ситуација и да омогуће прелаз од помоћи кроз опоравак до одрживог развоја. 


\section{Аналитички оквир}

Обнова је део процеса суочавања са последицама елементарних и других непогода. У доступној литератури елементи обнове су приказани као део процеса управљања катастрофама, почев од припрема за суочавање са последицама могућих догађаја, преко прве реакције на догађај, до реконструкције и нових планова (Слика 1). Контрола и смањење ризика је примарни циљ у фази припреме, која се одвија пре потенцијалног догађаја који може да доведе до катастрофе. У том процесу предузимају се мере које треба да смање вероватноћу реализације ризика, односно, уколико до њега дође да минимизирају штету. Припреме подразумевају поуздан модел предвиђања и на бази њега систем раног упозорења. Од тренутка испољавања догађаја почиње суочавање са његовим последицама. У првом кораку врши се процена последица и предузимају хитне мере како би се спасило угрожено становништво и умањиле материјалне штете. Након хитног одговора приступа се процесу реконструкције погођеног подручја, што подразумева поправку оштећених објеката и изградњу нових тамо где је поправка нерационална због степена оштећења (Possekel, 1999: 178).

Управљање ризиком

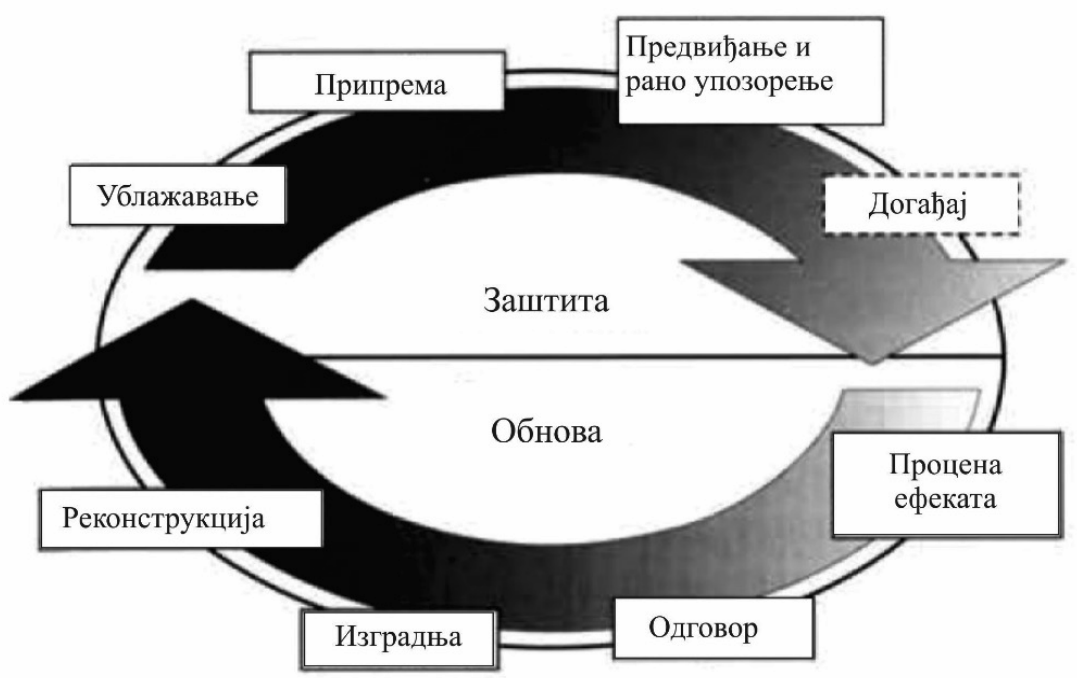

Управљање кризом

Слика 1: Циклус суочавања са последицама елементарних и других непогода Извор: преузето и прилагођено из: Wilhite et al., 2005. p.140. 
У току припрема за суочавање са последицама елементарних и других непогода треба имати на уму да је реч о мултидимензионалном процесу, који поред социјалног има економске, еколошке али и политичке аспекте (Platt, 1999). У датом контексту свеобухватан приступ проблему подразумева креирање модела и планирање уз коришћење социолошких, психолошких, политиколошких и метода економских наука. Израда квалитетних планова за спровођење процеса обнове подразумева идентификацију конкретних активности неопходних за успешно суочавање са последицама елементарних и других непогода. Поред постојања свести о значају планирања и потреби да се постојећи планови континуирано ажурирају у односу на актуелну ситуацију, неопходно је прилагођавање институционалних односа и система управљања ванредним ситуацијама у односу на промене амбијента. Анализа појединачних, групних и међунационалних односа у контексту институционалног амбијента представља полазну основу при процени ризика. За употребну вредност планова, познавање културолошког профила становништва и његовог односа према ризику, односно интересу заједнице, скоро је подједнако важно као и познавање институционалних механизама за управљање ванредним ситуацијама.

Процес планирања периода обнове подразумева одређене кадровске и институционалне капацитете који омогућавају приступ базиран на стратегији дугорочног решавања проблема у односу на потенцијалне ризике. Контрола ризика је могућа уколико у планове обнове уграђујемо претходна искуства у односу на локалне специфичности, тако да ситуацију након догађаја користимо као прилику за примену строжих грађевинских стандарда, измештање (дислоцирање) елемената критичне инфраструктуре и просторно усмеравање будућег развоја.

Након догађаја систем обнове и помоћи се активира у две фазе 3 . Најпре кроз краткорочне мере, где је примарна компонента помоћи у циљу збрињавања становништва са погођеног подручја. Циљ је да се путем предузетих мера и активности спасавају људски животи и умање материјалне последице догађаја. Међутим, већ у првом суочавању са последицама догађаја води се рачуна, где год је то могуће, и о дугорочним аспектима процеса. Циљ је да се избегне дуплирање операција у другој фази обнове, због чега се евакуација угроженог становништва спроводи на локацијама које нису обухваћене плановима за изградњу нових објеката. Након потраге и спасавања, односно збрињавања угроженог становништва и престанка непосредне опасности, приступа се дугорочној

3 Шире о фазном функционисању система обнове и помоћи у књизи Living with the Unexpected Linking Disaster Recovery to Sustainable Development in Montserrat (Possekel, 1999). 
фази обнове, која подразумева обнављање физичких, социјалних, еколошких и економских елемената на погођеном подручју. У првом плану је враћање оперативне способности јавних предузећа и инфраструктурних објеката, како би се на системском нивоу створиле претпоставке за процес обнове. Затим се приступа идентификацији оштећених објеката (домова и привредних субјеката) и процени да ли степен њиховог оштећења дозвољава поправку или је неопходно рушење и изградња нових објеката. Приликом процене степена оштећења врши се и процена локације - да ли је целисходно обнављати објекат и који је ниво ризика, односно вероватноће, да се понови исти сценарио. У складу са извршеним проценама приступа се уређењу погођеног простора уз примену свих техника контроле ризика, што подразумева и свеобухватну анализу ранијих догађаја који су доводили до ванредних ситуација на погођеном подручју.

Након елементарних и других непогода настају штете великог обима и њихова санација захтева предузимање обимних радова. С обзиром да је најчешће реч о крупним инвестиционим подухватима неопходан је мултисекторски приступ, како би ограничени фондови били што рационалније искоришћени. Некада је неопходна поновна процена ризика у односу на уочене недостатке у претходним проценама. Одвијање процеса зависи и од политичке воље, па зато увек треба да се води рачуна о пропратним ефектима и наглашавању постојећих друштвених проблема у условима ванредних ситуација, што захтева професионалан однос и избацивање субјективних елемената при доношењу одлука. При санацији терена и изградњи нових објеката, где год је то могуће, треба се руководити принципом: изіраяимо боле и квалииетеиније уреgимо иростиор.

\section{Суочавање са последицама елементарних и других непогода}

Суочавање са догађајем и његовим последицама је велики психолошки стрес за све који живе на погођеном простору. Грађани се могу суочити са губитком најближих сродника и познаника из непосредног окружења, а нису ретке ни ситуације са великим бројем повређених. У таквим околностима код људи се јавља и осећај кривице у односу на њихову улогу током догађаја, најчешће постављају себи питање да ли су могли да предузму нешто како би спасили људе који су страдали. Исти проблем се јавља и код професионалаца који учествују у процесу спасавања и због тога је неопходна стручна - психолошка помоћ, како би се превазишла криза и омогућило функционисање у датим околностима. 
У контексту психосоцијалних последица неопходно је што пре предузети кораке који ће грађанима погођеног подручја показати да систем функционише и да неко брине о њима. Није рационално очекивати оптималан број психолога за подршку у условима елементарних и других непогода, зато до изражаја долазе постојеће социјалне мреже, као и рад верских и непрофитних организација. Добар пример је деловање организације Црвеног крста 4 чије присуство на терену, поред практичних ефеката у виду спасавања и збрињавања повређених, обухвата и психолошку прву помоћ.

Паралелно са збрињавањем становништва ради се на ревитализацији јавне инфраструктуре, која је неопходна како за нормализацију живота, тако и за успостављање канала за достављање помоћи. Неопходно је оспособљавање путне инфраструктуре, енергетских мрежа, водоводних инсталација, канализационе мреже. У случају поплава ради се на предузимању мера како би се омогућило одводњавање и отклонили фактори који могу да покрену клизишта. Такође, у зависности од процене да ли постоји опасност од нових поплавних таласа, ради се на ојачавању насипа или поправци оштећених делова. Истовремено се ради на уклањању остатака од последица непогода, као што је опасан отпад, лешеви животиња, шут или наноси муља. Примарно је спречити испуштање штетних материја у животну средину, посебно оних које могу да доведу до контаминације воде за пиће. Врши се контрола ситуације око градских депонија, складишта опасних материја унутар производних погона и предузећа за прераду хемијског и других отпада.

Не мање важно је успостављање финансијских сервиса, како би становништво могло да користи сопствена средства или дознаке од пријатеља и родбине. Поред практичних ефеката, враћањем функционалности финансијског система постиже се и психолошки ефекат код становништва, коме се показује да постоји систем који је у стању да отклања последице елементарних и других непогода.

Што је пре могуће треба предузети неопходне мере како би се покренули привредни процеси на погођеном подручју. Наиме, ефекти елементарних и других непогода се манифестују кроз престанак пословања или су услови за његово одвијање крајње отежани. Имајући у виду чињеницу да су погођеном становништву потребна додатна средства како би се надокнадила изгубљена и поправила оштећена добра, неопходно је омогућити нормализацију у функционисању привреде. Може

4 Црвени крст је међународна хуманитарна организација која делује преко својих националних чланица. Универзални карактер хуманитарног рада обезбеђен је преко Међународне федерације друштава Црвеног крста и Црвеног полумесеца. 
се догодити да власници капитала, уколико процене да ће прекид у процесу производње дуго трајати, дислоцирају своје производне погоне на друга подручја и тако оставе без радних места локално становништво. Економски ефекти прекида привредних активности се не ограничавају само на погођено подручје, читав ланац у процесу производње, од коопераната, преко транспортера до крајњих купаца, трпи због застоја. У крајњем, и државни буџет остаје без дела прихода који се уплаћује у виду пореза и такси.

За ефикасност система обнове битно је обезбедити координационе тимове састављене од експерата, руководилаца јавних служби и представника власти. За адекватно и брзо реаговање некада је неопходан ауторитет властодржаца и моћ коју имају у систему по том основу.

\section{Елементии међународног систиема обнове и йомоћи}

Размере и учесталост елементарних и других непогода са катастрофалним последицама могу да доведу до масовних миграција становништва. Патње погођених и могући притисак на земље из окружења са последицама по регионалну али и геополитичку стабилност, намећу потребу за међународним организовањем са циљем пружања помоћи у случају елементарних и других непогода великих размера. Нема јединствених образаца за суочавање са последицама, то је сложен, понекад хаотичан, али увек комплексан процес. Сваки случај представља ситуацију за себе, профил опасности зависи од карактеристике региона, нивоа рањивости, развоја тока догађаја, система управљања, као и од културних, економских и политичких карактеристика простора. Сваки од наведених елемената утиче на ефикасност у суочавању са последицама елементарних и других непогода и на интеракцију земље са међународним агенцијама за управљање катастрофама и партнерским организацијама (Coppola, 2015, p. XXIII).

На глобалном нивоу учињени су одређени напори како би се успоставио међународни систем за реаговање у условима елементарних и других непогода када национални системи нису у стању да се изборе са последицама. Препоруке у документима који су усвојени у Хјогу и Сендају усмерене су, пре свега, ка малим и неразвијеним земљама које нису у стању да саме решавају проблеме, односно немају капацитете да самостално изграде систем реаговања у ванредним ситуацијама. У фокусу конференције из Хјога била је редукција ризика, а идеја је да се 
из ранијих искустава извуку законитости које могу на угроженим подручјима да допринесу смањењу нивоа ризика (UNISDR, 2007). Резултат конференције одржане у Сендају су препоруке за подизање ефикасности одговора на догађаје који погађају велики број становника и изазивају обимна материјална разарања (UNISDR, 2015).

У циљу операционализације закључака из Хјога и Сендаја, мандатом Генералне скупштине УН-а успостављена је Глобална платформа за смањење ризика од катастрофа (The Global Platform for Disaster Risk Reduction - GPDRR). GPDRR је међународни форум који се одржава сваке друге године, уз учешће међународних организација укључених у процес смањења ризика од катастрофа. Форуму присуствују представници националних влада, међународних организација, невладине организације, научне и академске институције и приватни сектор (UNDRR, 2019). Циљеви рада форума су:

- оцењивање напретка постигнутог у имплементацији Хјого и Сендај оквира за деловање;

- повећање свести о смањењу ризика од катастрофа;

- размена искустава и лекција из добре праксе;

• идентификација недостатака и препоручивање циљаних акција за њихово отклањање.

У процесу суочавања са катастрофама на међународном нивоу препознају се и следећи актери:

- погођена популација

• локалне структуре на погођеном подручју

- владе погођених земаља

- владе других земаља које се активно укључују у пружање помоћи

- међународне организације

- међународне финансијске институције

• регионалне организације и удружења

- непрофитне организације

- приватне пословне организације

• локални, регионални и остали донатори (Coppola, 2015, p.14).

Наведени списак и бројност укључених актера указују на висок степен сложености у функционисању међународног система за реаговање у условима природних и других непогода. 


\section{Функционисање система обнове и помоћи Републике Србије након мајских поплава 2014. године}

Маја 2014. године, Републику Србију погодиле су поплаве у размерама које нису забележене у претходних 120 година. Ова елементарна непогода угрозила је животе, здравље и имовину у 119 општина у централној и западној Србији. Најтежу последицу поплава представља губитак 56 људских живота. Након процене штете, на основу међународне методологије (Post Disaster Need Assessment - PDNA) (UNDP, 2019), утврђено је да укупна штета од поплава износи $€ 1,7$ милијарди или више од 4,5\% БДП-а. Рударско-енергетски сектор је претрпео највише штете (32\% од укупне), потом стамбени, пољопривредни и трговински сектор (око 15\% по сектору од укупне штете) (Уједињене нације, Европска унија и Светска банка, 2014: 16-19). У септембру исте године, источни део Србије (три општине Борског округа) такође је погођен поплавама.

\section{Искустива из мајских ӣойлава}

Влада Републике Србије је у току мајских поплава, на седници која је одржана 22. маја 2014. године, усвојила Уредбу о оснивању Канцеларије за помоћ и обнову поплављених подручја (Службени іласник РС, бр. 55/2014). Делокруг рада Канцеларије дефинисан је чланом 2 Уредбе, према коме Канцеларија обавља послове за потребе Владе, а који се односе на: координацију, праћење и извештавање у вези са хуманитарном помоћи која је упућена угроженима; израду мерила, критеријума и процедура за расподелу помоћи; израду периодичних и крајњих извештаја о додељеној помоћи; координацију и припрему делимичних и јединственог извештаја о процени штете; координацију припреме, спровођења и праћења плана санације; координацију извештавања о спровођењу планова санације; координацију, праћење и извештавање у вези са поступцима јавних набавки и остало. Такође, Канцеларија остварује сарадњу са свим државним органима, органима територијалне аутономије и локалне самоуправе, јавним предузећима, јавним агенцијама, установама и организацијама у области обнове поплављених подручја.

Након утврђивања одговорне институције која ће бити задужена за обнову, Народна скупштина Републике Србије 18. јула 2014. године донела је Закон о отклањању последица поплава у Републици Србији (Службени іласник PC, бр. 75/2014, у даљем тексту: Закон), као специјални закон, са престанком важења истеком једне године. Законом о измени Закона 
о отклањању последица поплава у Републици Србији, који је Народна скупштина Републике Србије усвојила 16. јула 2015, рок истека је продужен до 31. децембра 2015. године, када је процес обнове у РС и завршен.

Законом се уређује отклањање последица поплава, односно активирања клизишта на подручју погођеном поплавама у Републици Србији, које су наступиле у мају 2014. (члан 1 Закона). Списак општина и градова за отклањање последица предлаже Комисија за утврђивање штете од елементарних непогода, а усваја Влада Републике Србије. Рок за пријаву штете је 8 дана од дана ступања на снагу Закона, док се све штете пријављене пре доношења Закона сматрају благовременим (члан 44 3акона о отклањању последица поплава у Републици Србији).

Законом је мандат Канцеларије нешто измењен у односу на Уредбу, према чему Канцеларија поред послова из Уредбе припрема акт о начину верификације штета садржаних у извештајима о процени штета јединица локалне самоуправе, јавних предузећа и других облика организовања, чији је оснивач Република Србија. Извештај о процењеној укупној штети објављује на својој интернет страници, организује, координира и припрема државне програме обнове и остале послове прописане Законом (члан 4 став 3).

Начин спровођења обнове регулисан је чланом 2 Закона и врши се у складу са државним програмима обнове које доноси Влада, на предлог Канцеларије. Сходно члану 3 , државни програм обнове садржи следеће елементе: област и територију на којој се спроводе мере; анализу затеченог стања и настале штете; мере, критеријуме, начин, обим, редослед, рокове и одговорне органе у поступку спровођења мера, процену потребних финансијских средстава и изворе финансирања. Програми обнове израђују се на основу извештаја и налаза органа државне управе, стручних мишљења других органа и служби, јавних предузећа и других субјеката, надлежних органа јединица локалне самоуправе (члан 3 став 3 Закона). У циљу превазилажења недостатка системских решења, Државни програм обнове Влада Републике Србије формализује усвајањем 15 уредби.

5 Уредба о утврђивању Државног програма обнове оштећених породичних стамбених објеката (Службени іласник PC, бр. 77/2014); Уредба о утврђивању Државног програма обнове порушених породичних стамбених објеката (Службени іласник PC, бр. 77/2014); Уредба о утврђивању Државног програма обнове јавних објеката у сектору образовања (Службени іласник РС, бр. 100/2014); Уредба о утврђивању Државног програма обнове телекомуникационе инфраструктуре на поплављеним подручјима (Службени іласник PC, бр. 95/2014); Уредба о утврђивању Државног програма обнове оштећених електроенергетских објеката за пренос електричне енергије (Службени іласник РС, бр. 95/2014); Уредба о утврђивању Државног програма обнове оштећених електроенергетских објеката за производњу електричне енергије и набавке угља за потребе термоелектрана (Службени іласник $P C, 6$. 112/2014); Уредба о утврђивању Државног програма обнове оштећених електроенергетских објеката за дистрибуцију електричне енергије (Службени іласник PC, бр. 95/2014); Уредба о утврђивању 
Законом о отклањању последица поплава се, такође, дефинишу финансијски извори, који се обезбеђују из: буџета, донација; прилога и поклона; примања од задуживања; примања од продаје финансијске имовине; средстава јавних предузећа и других облика организовања чији је оснивач Република Србија, аутономна покрајина, односно јединица локалне самоуправе (члан 5 став 1 Закона). Закон је дефинисао и да уговоре о донацији, финансијској и другој помоћи упућеној Републици Србији, у име и за рачун Републике Србије закључује Канцеларија, чиме се обвезбеђује јединствено праћење свих прилива донација на једном месту (члан 5 став 3 Закона). Такође, у складу са овим законом, не плаћају се таксе, нити било какве накнаде за услуге републичких, покрајинских органа и органа јединица локалне самоуправе, а који се односе на поднеске, радње и издавање документације.

С обзиром да је штета након поплава 2014. године износила преко милијарду ЕУР, императив Владе у процесу обнове је био да се средства прикупљена за ове сврхе троше на јаван, праведан и сврсисходан начин. Као први корак провере тачности података о процени штета, Канцеларији је Законом поверен посао верификације подзаконским актима (Уредба о начину верификације штета садржаних у извештајима о процени штета јединица локалне самоуправе и других облика организовања чији је оснивач Република Србија - Службени іласник РС, бр. 84/2014), одређујући верификацију као стручни поступак којим се контролише исправност и тачност процене оштећења, а који врши комисија коју образује директор Канцеларије. Поступак верификације обавља се увидом у документацију и изласком на терен. Извештаји верификационе комисије се јавно објављују, а уколико постоје основи, о налазу се обавештава и надлежно јавно тужилаштво. Канцеларија је од 9. августа 2014. године до 31. децембра 2015. извршила верификацију укупно 16.848 објеката. У ситуацијама где постоји сумња да је при процени штете извршено кривично дело, Канцеларија је поднела кривичне пријаве

\footnotetext{
Државног програма обнове оштећених водних објеката за уређење водотока, водних објеката за заштиту од поплава, ерозије и бујица и водних објеката за одводњавање (Службени іласник РС, бр. 86/2014); Уредба о утврђивању Државног програма обнове у сектору саобраћаја (Службени іласник РС, бр. 86/2014); Уредба о утврђивању Државног програма обнове пољопривредним произвођачима на поплављеним подручјима за набавку минералног ђубрива (Службени іласник РС, бр. 103/2014); Уредба о утврђивању Државног програма помоћи регистрованом пољопривредном газдинству и породичном пољопривредном газдинству за обнову сточног фонда на поплављеном подручју (Службени іласник РС, бр. 103/2014); Уредба о утврђивању Државног програма обнове оштећених објеката рудне производње и снабдевања (Службени іласник РС, бр. 112/2014); Уредба о утврђивању Државног програма обнове за кориснике оштећених и порушених породичних стамбених објеката (Службени іласник РС, бр. 116/2014); Уредба о утврђивању Државног програма обнове привредне делатности на поплављеном подручју (Службени іласник РС, бр. 144/2014) и Уредба о утврђивању Државног програма обнове у сектору здравства (Службени іласник РС, бр. 4/2015).
} 
надлежном тужилаштву. Укупно је у поступку верификације поднето 659 кривичних пријава, сходно Извештају Канцеларије за период 20142015 (КПОПП, 2015).

За транспарентност поступака од значаја је и Уредба о начину извештавања о свим приливима и одливима средстава намењених за отклањање последица поплава (Службени іласник РС, бр. 105/2014). Све извештаје о потрошеним средствима и додели помоћи грађанима Канцеларија обједињује, извештава и објављује на својој интернет страници: obnova.gov.rs. Овим законским решењем успоставља се јасан систем контроле утрошка финансијских средстава, кроз јасне процедуре.

Законом се уређују и питања плаћања и јавних набавки. Канцеларија образује и води електронску базу података о одобреним и реализованим плаћањима из средстава намењених отклањању последица поплава, кроз Регистар плаћања (члан 9 Закона). Законом је поступак јавних набавки поједностављен због хитности обнове, при чему се за набавке добара, услуга и радова у процесу обнове примењује отворени поступак (члан 32 Закона о јавним набавкама), а не одредбе Закона о јавним набавкама, које се односе на план набавки, претходно обавештење, начин доказивања обавезних и додатних услова за учешће у поступку јавне набавке, рокове за подношење понуда и рокове за одлучивање Републичке комисије за заштиту права у поступцима јавних набавки (члан 12 став 4). Рокови за спровођење набавки су скраћени (члан 14), тако да рок за одлучивање о захтеву за заштиту права понуђача Републичке комисије за заштиту права износи пет дана, а три дана за жалбу против закључка наручиоца. Извештај о реализацији набавки спроведених према овом закону објављује се на интернет страницама Канцеларије и корисника јавних средстава који је спровео поступак набавке (члан 17).

Поглавље III Закона уређује поступак доделе помоћи физичким и правним лицима која пријављују штету надлежном органу јединице локалне самоуправе, према месту настанка штете (члан 40). Чланом 42 предвиђено је да се поступак за доделу помоћи води у складу са одредбама закона којим се уређује општи управни поступак, при чему, као поверени посао, поступак води надлежни орган јединице локалне самоуправе. Сви подаци о додељеној помоћи и о примаоцима помоћи представљају јавне податке и Канцеларија их објављује на својој интернет страници (члан 43).

3бог високог износа на који је штета процењена (1,7 милијарди ЕУР), одржана је Донаторска конференција у Бриселу, у јулу 2014. године, на којој су најављене билатералне донације у висини од 26,8 милиона евра. 
Солидарност након мајских поплава је била на високом нивоу. Велики број институција, предузећа, домаћих и међународних организација, појединаца из земље и иностранства, као и страних влада, уплатио је помоћ на наменски донаторски рачун. Канцеларија је успела током 2014. и 2015. године да подигне висину донација на 29,1 милиона евра. Бесповратна средства која је Канцеларија прикупила укупно су износила 220,7 милиона евра, од чега РСД 5,1 милијарди прикупљених на наменском рачуну Владе Србије, 26 милиона ЕУР билатерални донатори, 62 милиона ЕУР Фонд солидарности Европске уније, 30 милиона ЕУР средстава ИПА 2012, 60 милиона ЕУР средстава ИПА 2014 (КПОПП, 2017). У свом извештају, на страни 12, Канцеларија је дала табеларни преглед билатералних донација по земљама, као и степен њихове реализације на дан 31. мај 2015. године (КПОПП, 2015).

\section{Нова законска решења}

Након спроведеног процеса обнове и стечених искустава, Канцеларија је израдила нови правни оквир обнове, који представља функционално системско решење. Закон о обнови након елементарне и друге непогоде (Службени іласник РС, бр. 112/2015) сада уређује поступак обнове услед сваког нежељеног догађаја у свега 37 чланова. Закон се активира када Влада прогласи елементарну и другу непогоду (члан 5), која је дефинисана као догађај узрокован дејством природних сила или људском активношћу, који прекида нормално одвијање живота појединца и локалне заједнице и проузрокује материјалну штету већу од $10 \%$ буџета јединице локалне самоуправе.

У Закон је уграђен четврти приоритет Сендај оквира за смањење ризика 2015-2030 Уједињених нација, који даје препоруке за поступак опоравка и обнове. Поред примене принципа који се односе на равноправност грађана, заштиту рањивих група и јавност процеса, посебна пажња је посвећена начелу изградње бољег. Кроз процес обнове треба градити објекте и инфраструктуру који ће на системском нивоу друштво у целини чинити отпорнијим на будуће елементарне и друге непогоде (члан 10).

Квалитативна разлика новог у односу на стари Закон је обавезивање на предузимање мера ради смањења ризика од елементарних и других непогода (члан 2). Такође се регулише ко има право на помоћ и под којим условима. За привредне субјекте су постављени и посебни услови, који 
подразумевају да штета угрожава даљи опстанак привредног субјекта и да је настала од ризика који не осигуравају субјекти који се баве осигурањем имовине (члан 28).

Мере и критеријуме за пружање помоћи, односно мере, критеријуме и поступак за обнову и санирање последица елементарних и других непогода утврђује Влада државним програмима обнове, које доноси на предлог Канцеларије за управљање јавним улагањима 6 . Новим законом је задржана обавеза о поштовању прописаних процедура и јавности поступања, односно извештавања јавности о предузетим активностима.

\section{Закључак}

Фаза обнове након елементарних и других непогода је најмање у видокругу планера и служби које се баве ванредним ситуацијама. Углавном је акценат стављен на прву фазу хитне реакције у циљу спасавања људских живота и материјалних добара, односно умањења ефеката елементарних и других непогода. Изложена анализа би требало да укаже на значај фазе обнове у процесу отклањања последица елементарних и других непогода. Кроз процес обнове и помоћи нормализује се живот грађана на нивоу домаћинстава, достиже неопходан ниво функционалности јавног сектора (здравства, образовања, водовода, канализације) и покрећу привредне активности са циљем подизања нивоа отпорности на сличне догађаје у будућности.

Отклањање последица елементарних и других непогода захтева мултисекторски и вишефазни приступ, кроз координацију активности свих актера укључених у процес. Зато је неопходно да се у структури координационог тела нађу представници свих релевантних организација (јавно-комуналних и приватних предузећа), уз обавезно учешће високих представника власти, који захваљујући ауторитету својих функција доприносе ефикасности у функционисању система.

Ситуација са мајским поплавама 2014. године потврђује значај постојања добро институционално утемељеног система обнове и помоћи. Због системских недостатака Влада Републике Србије је морала да примени ad hoc решења. Међутим, захваљујући примени методологије ISDR и формирању Канцеларије за обнову и помоћ, као оперативног тела, у међувремену је успостављен систем, који је у релативно кратком року

6 Канцеларија за управљање јавним улагањима је правни следбеник Канцеларије за помоћ и обнову поплављених подручја (више о Канцеларији на: www.obnova.gov.rs). 
успео да нормализује ситуацију на погођеним подручјима. У пракси се показало колико је значајно постојање специјализованих организација (домаћих и међународних) за суочавање са последицама елементарних и других непогода великих размера. Захваљујући помоћи у људству, техници и финансијским средствима живот на погођеном подручју је нормализован. У међувремену су предузети кораци да се уочени институционални недостаци отклоне, што је, у највећој мери, постигнуто усвајањем нових законских решења и њиховом операционализацијом. 


\section{ЛИТЕРАТУРА}

Alexander, D. (1999). Natural Disaster. Dordrecht/Boston/London: Cluwer Academic Publishers.

Clement C. F. (1989). The Characteristics of Risks of Major Disasters, Proceedings of the Royal Society of London. Series A, Mathematical and Physical Sciences, Vol. 424, No. 1867 (Aug. 8, 1989), 439-459.

Coppola, D.P. (2015). Introduction to International Disaster Management. Oxford: Elsevier.

Lindell, M.K. (2013). „Recovery and reconstruction after disaster“. In: Bobrowsky, P. (Ed.). Encyclopedia of Natural Hazards (pp. 812-824). Heidelburg: Springer.

Nakagawa, Y. and Shaw, R. (2004). Social Capital: A Missing Link to Disaster Recovery. International Journal of Mass Emergencies and Disasters, 22(1), 5-34.

Platt, H. R. (1999). Disasters and Democracy: The Politics Of Extreme Natural Events. Washington: Island Press.

Possekel, A.K. (1999). Living with the Unexpected Linking Disaster Recovery to Sustainable Development in Montserrat. Berlin/Heidelberg: SpringerVerlag.

UNDP (2019): Post-disaster needs assessments, United Nations Development Programme. Преузето 10. јула 2019, ca https://www.undp.org/ content/undp/en/home/2030-agenda-for-sustainable-development/ planet/disaster-risk-reduction-and-recovery/post-disaster-needsassessments.html

UNDP \& EC (2011). Methodological guide for post-disaster recovery planning processes, Guidelines and actions for national, regional and local governments. Ecuador: United Nations Development Program \& European Commission.

UNDRR (2019) The Global Platform for Disaster Risk Reduction. The UN Office for Disaster Risk Reduction. Преузето 10. јула 2019. ca https:// www.unisdr.org/we/coordinate/global-platform

UNISDR (2007). Hyogo Framework for Action 2005-2015: Building the Resilience of Nations and Communities to Disasters. Geneva: United Nations International Strategy for Disaster Reduction. Преузето 10. јула 2019. ca https://www.unisdr.org/we/inform/publications/1037

UNISDR (2009). Terminologija Smanjenje rizika od katastrofa, Ženeva: Međunarodna strategija za smanjenje rizika od katastrofa.

UNISDR (2015). Sendai Framework for Disaster Risk Reduction 2015 - 2030. Geneva: United Nations International Strategy for Disaster Reduction. 
Преузето 10. јула 2019. са https://www.unisdr.org/files/43291_ sendaiframeworkfordrren.pdf

Quarantelli, L. E. (1998). What is a Disaster? Perspectives on the Question. London: Routledge.

Wilhite A. D., Botterill L., \& Monnik K. (2005). „National Drought Policy: Lessons Learned from Australia, South Africa, and the United States“. In: Wilhite, A. D. (Eds.) (2005). Drought and Water Crises - Science, Technology, and Management Issues (pp. 137-172). Boca Raton: Taylor \& Francis Group.

ФБ (2017). Master акаgемске ст̄иguје уйрављағьа ризииима оg елеменйарних и gруїих нейоїоga - ирроірам. Београд: Факултет безбедности. Преузето 18. новембра 2019. ca http://fb.bg.ac.rs/ studije/master-studije/studije-upravljanja-rizicima-od-elementarnihi-drugih-nepogoda/

КПОПП (2015). Извешйај о раgу Каниеларије за йомоћ и обнову йойлавлених йоgручја за йериоg мај 2014 - мај 2015. Београд: Канцеларија за помоћ и обнову поплављених подручја. Преузето 14. октобра 2019. ca http://www.obnova.gov.rs/uploads/useruploads/ Documents/Zakljucak_Godisnji-izvestaj-o-radu-KPOPP_maj-2014_ maj-2015.pdf

КПОПП (2017). Инфоїраф. 11.05. Београд: Канцеларија за помоћ и обнову поплављених подручја. Преузето 14. октобра, 2019, ca http://www. obnova.gov.rs/uploads/useruploads/Documents/Kancelarija-zapomoc-poplavljenih-podrucja-infograf-11-05-2017-srb-02.pdf

OEБC (2004). ENGLESKO-SRPSKI REČNIK TERMINOLOGIJE U OBLASTI UPRAVLJANJA OTPADOM, Beograd Misija OEBS u Srbiji i Crnoj Gori.

Уједињене нације, Европска унија и Светска банка (2014). Пойлаве у Србији 2014. Београд. Преузето 16. новембра 2019. ca http://www. obnova.gov.rs/uploads/useruploads/Documents/Izvestaj-o-procenipotreba-za-oporavak-i-obnovu-posledica-poplava.pdf 


\section{Закони и уредбе}

Закон о отклањању последица поплава у Републици Србији, Службени іласник РС, бр. 55 (2014).

Уредба о оснивању Канцеларије за помоћ и обнову поплављених подручја, Службени іласник РС, бр. 112 (2015).

Уредба о утврђивању Државног програма обнове оштећених породичних стамбених објеката, Службени іласник РС, бр. 77 (2014).

Уредба о утврђивању Државног програма обнове порушених породичних стамбених објеката, Службени іласник РС, бр. 77 (2014).

Уредба о утврђивању Државног програма обнове јавних објеката у сектору образовања, Службени іласник РС, бр. 100 (2014).

Уредба о утврђивању Државног програма обнове телекомуникационе инфраструктуре на поплављеним подручјима, Службени іласник PC, бр. 95 (2014).

Уредба о утврђивању Државног програма обнове оштећених електроенергетских објеката за пренос електричне енергије, Службени іласник РС, бр. 95 (2014).

Уредба о утврђивању Државног програма обнове оштећених електроенергетских објеката за производњу електричне енергије и набавке угља за потребе термоелектрана, Службени іласник РС, бр. 112 (2014).

Уредба о утврђивању Државног програма обнове оштећених електроенергетских објеката за дистрибуцију електричне енергије, Службени іласник РС, бр. 95 (2014).

Уредба о утврђивању Државног програма обнове оштећених водних објеката за уређење водотока, водних објеката за заштиту од поплава, ерозије и бујица и водних објеката за одводњавање, Службени іласник РС, бр. 86 (2014).

Уредба о утврђивању Државног програма обнове у сектору саобраћаја, Службени іласник РС, бр. 86 (2014).

Уредба о утврђивању Државног програма обнове пољопривредним произвођачима на поплављеним подручјима за набавку минералног ђубрива, Службени іласник РС, бр. 103 (2014).

Уредба о утврђивању Државног програма помоћи регистрованом пољопривредном газдинству и породичном пољопривредном газдинству за обнову сточног фонда на поплављеном подручју, Службени іласник РС, бр. 103 (2014).

Уредба о утврђивању Државног програма обнове оштећених објеката рудне производње и снабдевања, Службени іласник РС, бр. 112 (2014). 
Уредба о утврђивању Државног програма обнове за кориснике оштећених и порушених породичних стамбених објеката, Службени іласник РC, бр. 116 (2014).

Уредба о утврђивању Државног програма обнове привредне делатности на поплављеном подручју, Службени іласник РС, бр. 144 (2014).

Уредба о утврђивању државног програма обнове у сектору здравства, Службени іласник РС, бр. 4 (2015). 


\title{
RESTORATION AND ASSISTANCE SYSTEM - THEORETICAL BASIS AND FUNCTIONING IN THE REPUBLIC OF SERBIA
}

\author{
Ivica Đorđević, Associate Professor \\ University of Belgrade, Faculty of Security Studies \\ Sandra Nedeljković, MA in Political Sciences \\ Public Investment Management Office
}

\begin{abstract}
Summary
The system of reconstruction and assistance is the syntagm that best describes the process of addressing the consequences of natural and other disasters. Effective reconstruction involves adequate preparation, which includes training all potential actors in the process of assisting with the care for victims, as well as planning the necessary activities and resources needed in the process of reconstruction of the damaged and construction of new facilities. The frequency and magnitude of natural disasters with catastrophic consequences that exceed the capacity of nation-states led to the creation of an international assistance system. The International Disaster Reduction Strategy and the corresponding UN activities contribute to the promotion of the methodology gained from previous experiences. The establishment of an international relief mechanism also contributes to efficiency in responding to events with disaster elements.

The state of affairs in the Republic of Serbia in the aftermath of the floods in May 2014 confirms the importance of the existence of institutionalized mechanisms for efficient addressing natural and other disasters. Given that the national system for responding in states of emergency was not capable of finding the solution to the problem on its own, the Republic of Serbia
\end{abstract}


managed to cope with the situation after the floods thanks to the aid from international organizations and states that sent their teams of specialists. It is exactly because of this fact that the paper points to the importance of continuous work and preparations so that the community will be able not only to respond to challenges but also to preempt the emergence of events that may have catastrophic consequences.

Keywords: system, recovery, aid, disasters, May floods. 